7. Reprod. Fertil. (1965) 9, 343-346

BRIEF COMMUNICATION

\title{
PLAGENTAL WEIGHT LOSS IN LATE PREGNANCY
}

\author{
ANNE MCLAREN \\ A.R.C. Unit of Animal Genetics, Institute of Animal Genetics, Edinburgh
}

(Received 18th November 1964)

Summary. In two strains of mice, mean placental weight was less on the 19 th than on the 18th day of gestation.

Although the foetus is gaining weight rapidly towards the end of gestation, in most species examined the placenta reaches its maximum weight well before parturition (see Barcroft, 1946). In the mouse, after allowance had been made for number of implants, foetal and placental weights on the 18th day of gestation were positively correlated when the two uterine horns of individual females were compared (that is, the side with the larger placentae tended also to have the larger foetuses), but negatively correlated when comparison was made between different females (McLaren, 1965). This suggests that the mouse placenta actually loses weight towards the end of gestation: if physiologically more advanced pregnancies tended to have larger foetuses and smaller placentae the negative correlation would be accounted for.

To see whether the postulated weight loss could be detected directly, females of the C57BL/McL inbred strain were paired with males of their own strain and examined daily for copulation plugs. Of those that became pregnant, thirty-two were killed on the 18th and twenty-eight on the 19th day of gestation. (In this strain, litters are usually born on the 20th or 21st day. Smaller litters have longer gestation periods, see McLaren \& Michie, 1963.) Foetuses and placentae were removed, dissected free of the embryonic membranes, blotted lightly and weighed, using the same procedure as before (McLaren, 1965). The decidua basalis (maternal component of the placenta), which, by this stage in the mouse, makes up a very small part of the total placenta, was weighed along with the rest.

As expected, 19th-day foetuses were consistently heavier than their 18th-day counterparts (Table 1); for placentae, the reverse appeared to be true (Table 1 and Text-fig. 1). This was confirmed by statistical analysis: both bodies of data showed a significant negative regression of placental weight on number of implants surviving to mid-term; the slope of the regression did not change significantly between the 18th and the 19th day, but the downward shift in the position of the regression line was significant at the $2 \%$ level.

A further series of pregnancies, from the randomly bred local $Q$ strain, was examined to see whether or not the decrease in placental weight was confined to the notoriously aberrant C57BL strain. A few females killed on the 17th day 
of pregnancy were included. Table 2 shows that little obvious change occurred between the 17th and 18th days; between the 18th and 19th days, on the other hand, mean placental weight decreased by nearly $12 \%$. The decrease is highly significant $(P<0 \cdot 01)$.

\section{TABLE 1}

FOETAL AND PLAGENTAL WEIGHT ON THE 18Th AND 19TH DAY OF GESTATION (c57bL STRAIN)

\begin{tabular}{|c|c|c|c|c|c|c|}
\hline \multirow{2}{*}{$\begin{array}{l}\text { No. of implants } \\
\text { surviving } \\
\text { to mid-term }\end{array}$} & \multicolumn{2}{|c|}{ No. of pregnancies } & \multicolumn{2}{|c|}{$\begin{array}{c}\text { Mean foetal } \\
\text { weight }(\mathrm{g})\end{array}$} & \multicolumn{2}{|c|}{$\begin{array}{c}\text { Mean placental } \\
\text { weight }(m g)\end{array}$} \\
\hline & 18th day & 19th day & 18th day & 19th day & 18th day & 19th day \\
\hline 2 & 1 & 1 & $1 \cdot 185$ & 1.345 & 86.0 & 96.0 \\
\hline 3 & 2 & 1 & 1.021 & $1 \cdot 140$ & $87 \cdot 1$ & $83 \cdot 3$ \\
\hline 4 & 0 & 0 & & $1 . \overline{104}$ & $7 \overline{.9}$ & $0-0$ \\
\hline 5 & 3 & 2 & $\begin{array}{l}0.746 \\
0.800\end{array}$ & $\begin{array}{l}1.104 \\
1.100\end{array}$ & 86.4 & $\begin{array}{l}82 \cdot 9 \\
77 \cdot 0\end{array}$ \\
\hline $\begin{array}{l}6 \\
7\end{array}$ & $\begin{array}{l}0 \\
5\end{array}$ & $\begin{array}{l}3 \\
3\end{array}$ & 0.823 & $\begin{array}{l}1.053 \\
1.053\end{array}$ & 81.5 & 77.1 \\
\hline 8 & 10 & 6 & 0.812 & 1.103 & $79 \cdot 2$ & $74 \cdot 1$ \\
\hline 9 & 3 & 5 & 0.718 & 0.959 & 77.7 & $72 \cdot 4$ \\
\hline 10 & 1 & 3 & 0.824 & 1.084 & $80 \cdot 3$ & 67.9 \\
\hline 11 & 0 & 2 & - & 1.071 & - & $63 \cdot 7$ \\
\hline 12 & 0 & 0 & - & - & - & - \\
\hline 13 & 1 & 0 & 0.810 & - & $71 \cdot 3$ & - \\
\hline Total & 32 & 28 & & & & \\
\hline
\end{tabular}

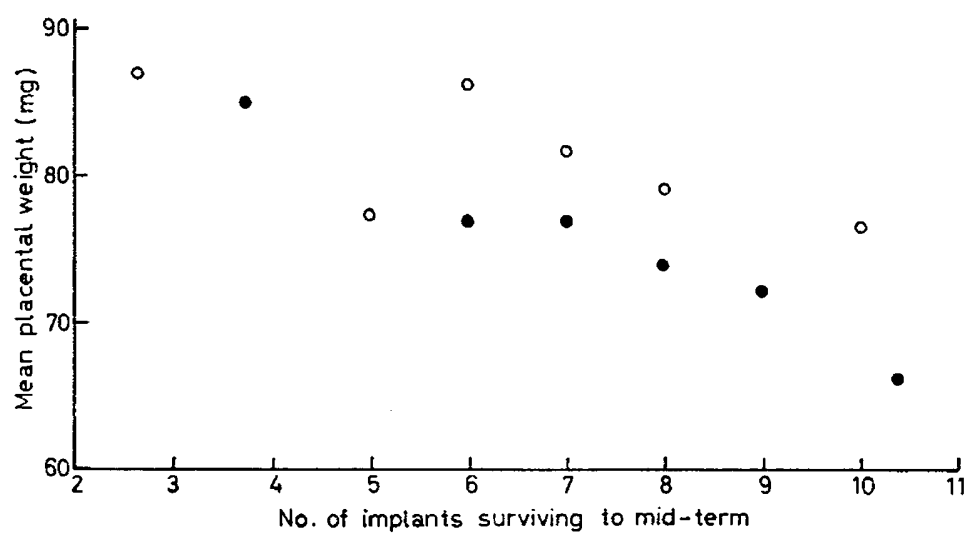

Text-FIG. 1. Mean placental weight in thirty-two 18th-day $(O)$ and twenty-eight 19th-day (๑) C57BL litters.

Little information exists as to how widespread this phenomenon is in mammals. Barcroft, Flexner, Herkel, McCarthy \& McClurkin (1935) reported that the rabbit placenta reaches its maximum weight around the 25th day; there is little sign in their data, or in that of Hammond (1935), of a decline thereafter. Elliott, Hall \& Huggett (1934) showed that in goats, too, maximum placental weight is reached some time before the end of gestation, but the data 
are too scanty to indicate whether there is any actual loss of weight. Barcroft \& Kennedy (1939) reported that sheep cotyledons (maternal and foetal combined) decline in weight for several weeks before term. Placental blood volume/gram weight of cotyledon, on the other hand, continued to increase while cotyledon weight was declining (Barcroft \& Kennedy, 1939). Limited data of Wallace (1948) suggest that the decline in weight is restricted to the maternal portions of the cotyledons. The extensive study by Cloete (1939) on prenatal development in sheep includes no data of relevance in the present context.

TABLE 2

PLACENTAL WEIGHT ON THE 17TH, 18Th AND 19TH DAY OF GESTATION (Q STRAIN)

\begin{tabular}{|c|c|c|c|c|c|c|}
\hline \multirow{2}{*}{$\begin{array}{l}\text { No. of implants } \\
\text { surviving } \\
\text { to mid-term }\end{array}$} & \multicolumn{3}{|c|}{ No. of pregnancies } & \multicolumn{3}{|c|}{$\begin{array}{c}\text { Mean placental } \\
\text { weight (mg) }\end{array}$} \\
\hline & 17th day & 18th day & 19th day & 17th day & 18th day & 19th day \\
\hline 6 & 0 & 1 & 1 & - & $105 \cdot 0$ & $121 \cdot 7$ \\
\hline 7 & 0 & 3 & 1 & - & $117 \cdot 1$ & $122 \cdot 9$ \\
\hline 8 & 0 & 1 & 8 & - & 102.5 & 97.3 \\
\hline 9 & 0 & 4 & 5 & - & $113 \cdot 6$ & $100 \cdot 0$ \\
\hline 10 & 3 & 7 & 4 & $114-5$ & $103 \cdot 6$ & 93.6 \\
\hline 11 & 0 & 9 & 6 & - & $111 \cdot 1$ & $100 \cdot 6$ \\
\hline 12 & 1 & 8 & 5 & $96 \cdot 7$ & 106.0 & 95.3 \\
\hline 13 & 1 & 4 & 4 & $100 \cdot 7$ & $109 \cdot 2$ & $89 \cdot 8$ \\
\hline 14 & 3 & 2 & 3 & 111.4 & $107 . \overline{5}$ & 91.7 \\
\hline 15 & 1 & 1 & 3 & $104 \cdot 0$ & 127.3 & 83.6 \\
\hline 16 & 0 & $i$ & 0 & - & $110 \cdot 0$ & - \\
\hline 17 & 0 & 0 & 1 & - & - & 91.9 \\
\hline Total & 9 & 41 & 41 & & & \\
\hline \multicolumn{4}{|c|}{$\begin{array}{l}\text { Mean litter size } \\
\text { Mean placental weight }\end{array}$} & $\begin{array}{r}12 \cdot 4 \\
108 \cdot 8\end{array}$ & $\begin{array}{r}10 \cdot 9 \\
109 \cdot 2\end{array}$ & $\begin{array}{l}10 \cdot 8 \\
96 \cdot 5\end{array}$ \\
\hline
\end{tabular}

Ibsen (1928) weighed the foetuses and placentae of a large number of guineapigs killed at different stages of pregnancy, and comments: "As a matter of fact, there are even indications in the later stages that there is an actual loss of weight of the placentas in those cases where there is a large number in one uterus". His data, which relate to the foetal part of the placenta only, are printed in extenso. It is therefore possible to calculate the regression of placental weight on day of pregnancy for each litter size (2 to 7): from about Day 60 onwards, all six regression coefficients are negative, and the overall effect is highly significant. The loss of weight is in fact manifested in small litters no less than in large ones.

Whether the decrease in weight of guinea-pig and mouse placentae in late pregnancy involves an actual loss of substance, or merely a fall in the volume of blood which they contain, cannot be ascertained from the data at present available. It may be relevant that Flexner \& Pohl (1941) observed in rats that the transfer rate of sodium from mother to foetus dropped sharply a day or so before parturition. 


\section{REFERENCES}

Barcroft, J. (1946) Researches on prenatal life, vol. 1. Blackwell Scientific Publications, Oxford.

Barcroft, J., Flexner, L. B., Herkel, W., McCarthy, E. F. \& McGlurkin, T. (1935) The utilization of oxygen by the uterus in the rabbit. 7 . Physiol. 83, 215.

BARCROFT, J. \& KENNEDY, J. A. (1939) The distribution of blood between the foetus and the placenta in sheep. F. Physiol. 95, 173.

Gloete, J. H. L. (1939) Prenatal growth in the Merino sheeps. Onderstepoort 7. vet. Sci. 13, 417.

Elliotr, R. H., Hall, F. G. \& Huggett, A. St. G. (1934) The blood volume and oxygen capacity of the foetal blood in the goat. 7. Physiol. 82, 160 .

Flexner, L. B. \& Pohl, H. A. (1941) The transfer of radioactive sodium across the placenta of the white rat. F. cell. comp. Physiol. 18, 49.

HAMmond, J. (1935) The changes in the reproductive organs of the rabbit during pregnancy. Trans. Dynamics of Development, Moscow, $10,93$.

IbSEN, H. L. (1928) Prenatal growth in guinea-pigs with special reference to environmental factors affecting weight at birth. F. exp. Zool. 51, 51 .

McLaren, A. (1965) Genetic and environmental effects on foetal and placental growth in mice. 7. Reprod. Fertil. 9, 79.

McLaren, A. \& Mrahie, D. (1963) Nature of the systemic effect of litter size on gestation period in mice. F. Reprod. Fertil. 6, 139.

Wallace, L. R. (1948) The growth of lambs before and after birth in relation to the level of nutrition. Part 2. F. agric. Sci. 38, 243. 